\title{
The Meanings of a Star: Interpreting Music Fans' Reviews
}

\author{
Phillip Vannini \\ Washington State University
}

\begin{abstract}
This article both elaborates on and empirically supports Norman Denzin's thesis on the political aesthetics of interpretation. Through a reading of consumer reviews, I discuss both the image and the music of the contemporary pop star Avril Lavigne by combining analytic tools derived from dramaturgy and social semiotics. Specifically, I present consumer reviews of Avril Lavigne's public persona as interpretive acts that decode the practices of production, distribution, and consumption of her alleged subcultural authenticity. I discuss the importance of understanding interpretation as a practice of cultural resistance against the pervasive force of consumerist ideologies and hegemonic mass media discourses. In addition, I reflect on the usefulness of a symbolic interactionist approach to a cultural studies based on Peircean semiotics and Goffmanian dramaturgy.
\end{abstract}

We are losing control of the very means of cultural production itself. ... More and more culture becomes an adjunct of marketing, or of the bureaucratic ethos, or of both. —C. Wright Mills (1963:226)

Many of our contemporary lifestyles are said to have assumed the character of political and aesthetic projects (Featherstone 1991). However, a hegemonizing mass aesthetics that commodifies life and the meaning of many symbolic acts has arguably emptied many lifestyles of their unique and creative expressiveness (Mills 1963). Clearly, when mass-marketed commodities mediate creative expression, the "authenticity" of individuals' lives and group culture is imperiled. Many pessimistic cultural commentators have given attention to the alleged inauthenticity of such an existence and culture (for a review, see Kroker 1992), but fewer have examined the interpretive practices of resilient selves challenging cultural hegemonies (for some notable exceptions, see Ang 1985; Cohen and Taylor 1978; Fiske and Hartley 1978; Hebdige 1979, 1988; Radway 1984). As symbolic interactionists we must resist

Direct all correspondence to Phillip Vannini, Department of Sociology, Washington State University, Pullman, WA 99164-4020; e-mail: vannini@lycos.com.

Symbolic Interaction, Volume 27, Number 1, pages 47-69, ISSN 0195-6086; online ISSN 1533-8665. (c) $\mathbf{2 0 0 4}$ by the Society for the Study of Symbolic Interaction. All rights reserved.

Send requests for permission to reprint to: Rights and Permissions, University of California Press, Journals Division, 2000 Center St., Ste. 303, Berkeley, CA 94704-1223. 
fashionable cynical views that argue that meaningless mass-mediated symbols and useless commodities have annihilated the subject and at the same time responsibly account for the power of these processes.

This article develops Norman Denzin's (1992:133) argument that a political aesthetics of interpretation of mass-mediated and commodified cultural products "transcends traditional views of the aesthetic experience [and] calls for a cultural criticism based on a pragmatic political aesthetics of experience." While the classical conception of aesthetics sees it as that branch of philosophy concerned with the study of abstract principles of beauty, especially in artistic expression, Denzin (1992) defines aesthetics as a pragmatic politics of experience that is found at the genesis of experience itself-the existential moment of interpretation of one's lifeworld. Because one's lifeworld in the postmodern era inevitably entails the experience of mass-mediated symbolic meanings, an understanding of the political aesthetics of interpretation has to begin in both the symbolic and the physical realms of popular culture and everyday life (see also Barthes 1972).

This article focuses on this universe of popular culture, particularly on the public image and music of the pop star Avril Lavigne. Popular music is a complex amalgam of various structural and cultural relations that go well beyond the "classical" realm of the aesthetic (Barthes 1985; Frith 1996). Indeed, the aesthetic realm has never been free of either politics (Becker 1982) or ethical judgment (Frith 1996). Whether highbrow, folk, or pop, music as a form of art is embedded in the economy and culture. ${ }^{1}$ Music interpretation is thus a social practice-a practice that in the late capitalist era works as a form of decoding of the ideological meanings inscribed into the art-turned-commodity by its commercial producers (Hall 1980). Denzin (1992) sees Dewey as the originator of this approach to interpretation in symbolic interactionism. For Dewey (1934), the aesthetic experience is a form of interaction with an expressive object, the work of art. The expressiveness of the work of art lies in its emergent symbolic meaning, which challenges everyday taken-for-granted meanings because art questions reality by blurring the boundaries between imagination, the self, the expressive object, and its environment. There is neither absolute nor ultimate reality in art, neither final nor correct interpretation, but only the encounter between the self and the open meaning of the work of art (Dewey 1934). The study of processes of construction (or staging) and interpretive deconstruction (or interpretation) of a popular music persona allows us to reflect on how individuals manage mass-mediated and staged appearances of a self and how others interpret them.

I first introduce Lavigne by approaching her public persona as a performative production. Next, I briefly discuss Denzin's (1992) thesis on the political aesthetics of interpretation and review the basic foundations of sociosemiotics. In the third section I present my reading of consumer reviews of Lavigne's music and image and discuss my research findings. I conclude by commenting on the politicocultural consequences of polisemy and the meaning of performative resistance to cultural hegemonies. 


\section{AVRIL LAVIGNE: A “COMPLICATED" TEXT}

Few people were familiar with Avril Lavigne before spring 2002. But today, this Ontario-native teenage star can claim to have taken the music world hostage to her catchy pop-punk hooks and intriguingly "different" "skateboarder" looks. Her first CD, Let Go, in particular, her first single, "Complicated," has reached the top of the Billboard charts, earned nominations for Best Pop New Artist and Best Pop Female Artist at the 2002 Billboard Music Awards, received five Grammy nominations, and won the Best Song, Best CD, Best Female Artist, and Best Homework Song at the 2002 Radio Disney Music Awards, as well as the MTV Video Music Award for best new artist in a video. Let Go went platinum on July 12, 2002, only a handful of weeks after its release-breaking all-time records for short-time increases in sales and radio spins. By November 2002 Let Go had sold 3.6 million copies in North America and 6.2 million worldwide (Lee 2002). Lavigne has graced the cover and pages of innumerable magazines and newspapers, including Seventeen, Chart Attack, YM Magazine, Elle Girl, Rolling Stone, Time Magazine, the New York Times, US Weekly, and USA Today. Access Hollywood, VH-1, and MTV have dedicated a number of specials to Lavigne, and her guest appearances on late-night shows, her music videos, and Top 40 radio station play have made her one of the most famous teenagers in the world.

Could this latest pop culture product be any different from others? The answer might be a definite yes if we were to ask her diehard fans. But the construction and deconstruction of Avril Lavigne's difference and authenticity seems a bit more complicated than that. In fact, the argument I develop here suggests that although Lavigne's style or music is not that original, its popularity deserves attention. Her originality is constructed through a process known as hyperdifferentiation, that is, the process whereby producers of commodities seek to create significant differences between them in order to expand the market of consumers (Crook, Pakulski, and Waters 1992; see also Adorno 1991). By studying reviews, then, we can observe how consumers' interpretive practices work to further the hyperdifferentiation process or to deconstruct it. Thus combining dramaturgy and social semiotics to study Lavigne's public persona as a symbolic commodity can enhance our understanding of the contemporary dynamics of popular culture.

Interpreting the symbolic meaning of an object of art, whether it is categorized as "high" or "pop" culture, is an aesthetic experience that is political in nature and culturally defined (Denzin 1992; Frith 1996). Denzin (1992:135) argues: "In the aesthetic experience turned political, the individual experiences heightened feelings of moral worth, often coded in masculine-feminine, in-group, out-group terms. Such moments produce feelings of in-group solidarity and out-group hostility. Conduct is directed to the salient political stereotypes of the culture, and an exaggerated sense of self-worth is experienced." Similarly, Frith (1996:8) suggests that "popular cultural arguments . . . are not about likes and dislikes as such but about ways of listening, about ways of hearing, about ways of being." A political aesthetics of interpretation 
is thus a cultural practice rooted in a specific interpretive community (Fine 1977). In addition, within each community diverse and often opposed subcommunities, artistic genres, and value systems will compete with one another for the power to define political and aesthetic meanings (Denzin 1992; Frith 1996; Grossberg 1992). To understand how Lavigne's public persona is interpreted, then, we must look at how various audiences interpret the meanings of her symbolic practices.

It is not with Avril Lavigne as a private individual self that I am concerned but rather with her public persona. We need to understand this public persona as a complex performance that can be studied analytically (Denzin 2003). Clearly, a popular musician does not just stage her public persona through music play but also through impression management practices of her style, body appearance, and life story (Frith 1996). In dramaturgic terms, the interpretation of Lavigne is a process that poses questions about her public front. Lavigne stages her front in the interactional order of our postmodern society in which the mass media play an important role (Goffman 1979; Meyrowitz 1985). Her public persona then emerges out of a complex interplay of her performances and stories, as well as the public interpretations of these appearances and the frames audiences use to understand them (Goffman $1959,1967,1969,1974)$. This persona is constructed through the negotiation of symbolic meanings pertaining to various codes, including the biographical (her age, career course, life story), the sociostructural (her public status as a celebrity figure), the sexual (her sexual appeal but also her performance of femininity), the politicoeconomic (her work status as the employee of a major multinational corporation), and the aesthetic (her worth as a pop-punk musician and as a style and fashion follower and trendsetter) (see Denzin 1992).

A dramaturgic approach can be easily combined with a sociosemiotic one. As audiences confront Lavigne's persona, they interpret her staged performances (both musical and nonmusical) in a defined cultural, historical, aesthetic, experiential, and politicoeconomic context. These performances are always symbolic and, as the diversity of reviews show, are open to different interpretations. This principle lays at the foundations of a sociosemiotic approach based on Peircean semiotics (Peirce 1960). Peirce (1960) views the sign as composed by an object, a vehicle conveying a mental idea of the object (called representamen), and the actual idea evoked by the representamen in the interpreter's mind (called interpretant). Therefore, a sign may have more than one meaning, and it is thus said to be polysemic. ${ }^{2}$ Sociosemiotics also recognizes the importance of analyzing the exosemiotic context in which signification takes place by looking at how hegemonic ideologies ${ }^{3}$ and the political economy enter the signification process and its context (Gottdiener 1994).

Because meanings are always "symbolic, never singular, always multiple, and always carried through the process of direct and mediated communication" (Carey 1989:64-65), a sociosemiotic, dramaturgic, and symbolic interactionist approach to the production, distribution, and consumption of symbolic cultural meanings can be very useful. Such an original approach analyzes how these meanings are lived and experienced and "attempts to unravel the ideological meanings that are coded into 
the taken-for-granted meanings that circulate in everyday life" (Denzin 1992:34). At the same time, although media messages are often encoded for us by their producers and distributors and contribute to defining the structures and meanings of everyday life (Lefebvre 1971), consumer audiences retain the ability to resist media messages and engage in alternative readings and interpretations (de Certeau 1990; Hall 1980). In dramaturgic terms, audiences can interpret a performance as genuine or false.

\section{METHOD AND DATA}

Traditionally, the function of the music critic was to "explain the music to the public, [and to] teach it how to listen" (Frith 1996:64). Reviewers were thus considered expert professionals in charge of bridging the gap between the artist and the consumer and responsible for the maintenance of high standards (Frith 1983, 1996). Reviews of live music performances and recordings were almost exclusively concerned with sound and less with issues of image, style, and the "scene"-as the latter concerns were viewed with suspicion and as symptomatic of more superficial popularity than art. Later, as popular music gained commercial favor and as communication technologies made giant leaps to facilitate reproduction and transmission, music began to be broadcast on television through live concert coverage, music videos, behind-the-scene specials, and so on, and the sound of music began to occupy a less central position (Kaplan 1987). The birth of early television shows such as American Bandstand and later of television channels that broadcast only music sound accompanied by visual elements, such as MTV and VH-1, attest to these changes. Throughout the past two decades or so this tendency toward the multimodality of music has increased greatly: popular music is now far more than just sound, and a fan is more than just a listener (DeNora 2000). A quick glance at the above-mentioned television channels today quickly confirms the previous argument: music videos, concerts, and other sound-centered performances are somewhat of a rarity in the midst of programming far more focused on lifestyle. There is of course music sound in these mediated representations of lifestyle, but a discussion of the meanings of music cannot neglect fashion, style, sexual appeal, bodily practices, gossip, and so forth.

In this context, music reviews are also significantly different (see Frith 1983). First, the professional reviewer's influence has largely diminished. Frith (1996) notes that the music critic is now a fan; this change reflects a broad democratization of the aesthetic experience, in part facilitated by the erosion of the boundaries between high and low culture. Popular music is now piped in everywhere and, much like in a post-Trent Council Protestant revolution, music followers hardly need the mediation of professional interpreters to decide what is best for them. Second, the concept of reviewing is no longer confined to interpreting just the sound but now includes various aspects of a multimodal performance that is as much aural as it is visual. These factors have given birth to the amateur (or consumer) reviewer. An amateur reviewer is first and foremost a consumer and not an art critic in the traditional 
sense; hence he or she does not need to undergo formal education or become a music industry insider like the professional reviewer does. Third, a consumer reviewer is not compensated monetarily to write a review for a press source. Fourth, as the reviews collected for this article attest, a fan-critic is a consumer and as such reviews a musical commodity for its use value, exchange value, and symbolic value rather than for its musical aesthetic value. This consumer reviewer is thus not a gatekeeper of Top 40 hits but rather an active member of its target market who may or may not like or elect to buy the marketed product.

Today, professional reviewers of pop music write for mainstream specialized newsstand publications such as Rolling Stone, Spin, and New Music Express and for a number of nonspecialized newspapers and magazines. These reviewers are compensated for their services and are still, in most cases, formally educated in the humanities. In contrast, amateur reviews are never found in newsstand publications but are instead commonly found on the Internet in e-zines, forums, message boards, and especially shopping sites available to the reading public free of charge. Because my focus here is on consumers rather than professional reviewers, all reviews by compensated and trained professional critics written for publications on sale on newsstands were excluded from the data collection. Thus we can define a consumer or amateur review as any review written by someone other than the professional described above.

To understand how consumers interpret Avril Lavigne, I collected a total of 1,171 consumer reviews published on the World Wide Web and located through a thorough engine search. I collected the greatest majority of reviews from two highly visited Web sites, Amazon.com and Yahoo.com. ${ }^{4}$ I collected the remaining reviews from other less popular shopping Web sites and a small number of sites open to the general public. Many of these reviews were written under pseudonyms (Internet handles) and lacked background information about the author. Obviously, this is not a representative sample, but the purpose of this article is not to make quantifying generalizations about all fans of Avril Lavigne. I obtained permission to reproduce all passages reported below from the Web sites and the reviewer whenever either could be contacted via e-mail. In cases in which the reviewer could not be contacted and in which the review was submitted without knowledge that this information would be available in the public domain, I did not reproduce it in this article but did include it in the data analysis.

Consumer reviews are now welcomed by numerous Web sites. For example, Amazon.com and Yahoo.com ask visitors to their sites to criticize any of the products offered for sale, such as CDs. After registering gratis on the site, any user can write a freely produced text that other visitors can browse. Reviews are not edited and are automatically published, provided they are pertinent and more or less free of obscenities. A similar process is at work in many of the "shopping" Web sites that contained reviews. These reviews are welcomed by commercial Web sites because they offer potential shoppers the opportunity to learn more about products directly from "consumers like them" rather than from professional and expert reviewers. I 
collected other reviews, a very small number, from free-of-charge noncommercial music and pop culture Web sites and posted on pages in the sites, much like letters to the editor are printed in a newspaper. Finally, I collected reviews that were posted by the Web site administrators and that express their opinions on this matter.

Only one study has looked at professional music reviews (Frith 1983), and no study except the present one has looked at consumer reviews. Despite Frith's (1996) illuminating discussion of value judgments in pop music, there is much that we need to know about this practice. There are complex social psychological dynamics at work here that deserve the full attention of future empirical investigation. However, the purpose of this article is simply to conduct the first empirical analysis of music consumer reviews in order to understand the practice of interpretation of a public persona. This meta-analytic method for the study of interpretation is advocated by sociosemioticians such as Gottdiener (1994).

It is important to note that this is not a traditional manifest content analysis and therefore does not provide word counts, themes, or categories such as would usually be employed. Furthermore, rather than validity and reliability in the traditional sense, I must here rely on intersubjectivity. This is difficult but not impossible. Just as any consumer reviewer of Avril Lavigne may reach different conclusions regarding her music and persona, any meta-reviewer of these reviews may engage in different textual readings of these reviews. The difficulty inherent in interpreting interpretations has been discussed by Radway (1984), who creatively combined content analysis, structural semiology, interviewing, and reader-response criticism to analyze a group of female readers' interpretations of paperback romance novels. Because of this intrinsic difficulty in judging reviews, I abstained from presenting simplistic statistics describing which and how many readings fall under which category. Polysemy should not, however, deter us from scholarly studies. In fact, it should be immediately clear that certain reviews are inexorably and undoubtedly negative, whereas others are positive. Positive reviews are those that clearly accept the "preferred" meanings of Lavigne's music and public persona, whereas negative reviews clearly dismiss those (Hall 1980). From a dramaturgic perspective, when audiences engage in preferred readings they interpret an actor's performance as true, whereas an oppositional reading interprets the performance as false. Combining sociosemiotics with dramaturgy allows us to focus on ideology and thus to sharpen the polemical potential of Goffman's work. ${ }^{5}$

All reviews that appear here are representative of the larger sample of reviews I analyzed. In other words, the excerpts reported here stress the most common arguments that reviewers make in relation to Lavigne's music and persona (e.g., her clothing style, skateboard skills, vocal delivery, song lyrics). I selected these excerpts also because they are fairly clear and concise. My hope is that by reporting extensive excerpts from as many reviews as possible (given space limitations) and by being as transparent as possible about the analytic framework used to analyze them, others can independently assess the validity of my interpretation. While I do not pretend to be objective, I strive to be descriptive, persuasive, and critically 
interpretive. The sociosemiotic method and analytic approach I use here complements Radway's (1984) approach by integrating sociosemiotics and dramaturgy and also builds on Fairclough's (1995) critical discourse analysis as it examines textual practices and their sociocultural significance. Finally, this method transcends the limitations of Fiske and Hartley's (1978) semipositivistic and structural-semiological analysis of media messages in two ways: (a) it understands media culture as a contested terrain in which various interpretive communities interact to shape hegemonies, in the processual sense intended by Gramsci (1971), and constantly compete over time with others for the definition of genre boundaries; and (b) it takes into consideration how the posting of reviews on the Internet turns an individual and private interpretation into a public statement. Given the high interactivity of Internet message board-type forums like Amazon.com and Yahoo.com, this method seems quintessentially interactionist and semiotic.

\section{INTERPRETING AVRIL LAVIGNE}

The purchase of music (and possibly the style associated with it) such as Lavigne's Let $G o$ is far from being an inconsequential and mundane activity (see, e.g., Kotarba 2002). If we are to believe that everyday practices continuously reproduce macro structures and power inequalities we must consider the everyday as the primary site for the operation of ideological systems. But, contrary to classical Marxist approaches, we must, as symbolic interactionists, keep in mind that individuals have the power to resist and challenge hegemonic ideologies. From a sociosemiotic point of view, when interpretations fail to question taken-for-granted meanings (typically encoded in a text by its producers), we may call such interpretation a preferred reading. When, on the other hand, audiences question the taken-for-granted meanings encoded in a text and uncover the working of ideology, we may refer to such interpretation as an oppositional reading (Hall 1980).

\section{Preferred Readings}

Avril Lavigne's persona is constructed and staged as "authentic,"6 and it is this alleged authenticity that has in part contributed to her success. As Frith (1996) has observed, audiences evaluate the authenticity of a pop music performer on the basis of her sincerity. In other words, fans "expect music to mean what it says" (p. 71). As the following excerpts show, authenticity is also closely related to autonomy and creativity. ${ }^{7}$

Hey, I wish people would stop saying such bad stuff about Avril! So she's a punk. So? Get over it! That's how she likes to express herself. Not everyone likes to be the same as everyone else.

This CD is the best! I love it! All of the songs are great, and Avril is a totally cool person. She does everything her own way and doesn't let anyone stand in the way of her dreams! 
Yeah she's punky and I hope she puts more songs out. If you like Avril, then get the CD! I am hooked on it! Get it! You will be satisfied with your purchase. She wrote all her songs AND plays her own music. She is so good! You all really need to try this CD out. I am so glad I did!

Avril Lavigne dropped out of high school to pursue her dream career when she was sixteen. By that time she already had an opportunity to sing in public. After winning a talent contest, she was selected to sing one song live onstage in a duet with the pop-country star Shania Twain. The story goes that she later embarked on a trip to New York and Los Angeles with her (then) manager, Cliff Fabri. After auditioning for Arista Records, she signed a contract worth \$1.2 million (Lee 2002) and accomplished her dream of making music records "her own way," that is, by refusing to compromise with her producers' demands and by asserting her punk independence and skateboarder image. There are other stories, however, that seem to undermine her artistic authenticity. According to a New York Times article (Lee 2002), it is Cliff Fabri who clued her in about punk, and her image, music, and life stories were then as carefully manufactured by Arista as those of any other popular persona. It is indeed a common practice to "manage" personal narratives told to audiences to achieve desired results. Popular culture stars' life story details are easily available to mass audiences, who use those to judge the stars' personae and products. Producers are obviously aware of the importance of presenting an artist's coherent life story to audiences, and thus life stories are turned into commodities-marketing tools that are strategically managed to enhance reputations and credibility. Clearly, the mediated representation of a self and staging of a public persona is a process conducted according to marketing criteria.

Lavigne's alleged authenticity is staged through the narrative construction of her dedication, ambition, striving, confidence, and pure talent. For this performance of authenticity to work effectively, Lavigne's persona must be different from other, related signs, texts, personae, and performances. Semiotically speaking, this comparison is a paradigmatic analysis, which works by grouping together units of a system and contrasting their similarities and differences. We can observe how this works by taking a look at the following review excerpts:

Sick of the boring voices of Britney Spears and Christina Aguilera? Well, Avril Lavigne is the person to listen to. Her songs sound so much more realistic (she writes her own songs) with lyrics you're able to relate to. The songs sound a little rockish with a tiny tint of country (don't worry, it's not strong at all). She has a pretty voice, and I would definitely recommend this CD to those rockers and punk rockers out there.

Avril is a very talented young woman. Her lyric maturity needs to expand a little, but she's just 18, and the fact that she had a part in the songwriting of every track says a whole lot. You don't see Mandy or Britney taking so much of an effort on writing their own lyrics. She is original and I don't think she's trying to be someone she's not, like most singers do today.

In this case, a paradigmatic analysis works by comparing Avril Lavigne to other popular female performers in the same genre. Britney Spears, Christina Aguilera, 
Mandy Moore, and other teen pop stars are here implicitly branded as fake, boring, manufactured, and overproduced in comparison to the pure heart-and-soul approach of this "real girl" speaking up for "real girls." Some consumers interpret Lavigne's persona as authentic by virtue of her differences from similar others. But in contrast to Saussurean semiology, meaning is not exclusively determined by the position of a sign in a structure of signification. Indeed, the coding and decoding of meaning takes place in interaction in specific contexts that must be carefully considered.

The position in sociosemiotics is that commodities are signs that acquire their meaning in part, but not exclusively, by virtue of their difference from other commodities in what is known as a politicoeconomic system of signification (see Denzin 1987). In the case of Avril Lavigne, specific meanings are coded into the staging of her persona in different ways, for example, through the use of props like the skateboard, the arm-sock, and the necktie, to differentiate her from other performers (see Crook, Pakulski, and Waters 1992). These signs serve to set her apart from other pop stars in order to appeal to the lifestyles of specific consumers, as the following review suggests.

When Avril first came out with her song "Complicated," I really enjoyed listening to this on MTV. The music video really showed how people live and how they like to do the weirdest things (kind of sounds like myself ... LOL).

Some consumers identify with these signifying commodities because they interpret them as a material representation of their own identities. These consumers, especially teenagers, then might invest monetary resources in purchasing related commercial signs that express and validate their identities. What is being sold, therefore, is not just a CD but the representation of a lifestyle. Anecdotal evidence from concertgoers testifies to this: it is quite common for fans to wear the same clothes, accessories, and body modification gear worn by their idols. Mindful of this, many urban and suburban music chains such as Hot Topic, Tower Records, and Virgin stores now sell related clothing, accessories, and reading material as well as CDs. Buying Avril Lavigne's music or style sets a consumer apart from others who buy, say, Britney Spears's music or style, and this consumer will go to great lengths to purchase signifiers that communicate that he or she is a dedicated fan, as the following review demonstrates.

I'll tell ya now, this is the only CD I listen to now, and I will buy her next CD. I put it on my car's CD player every time; I can never get enough of her. I am even looking for Nokia 3390 Ringtones of her songs! I love Avril Lavigne. Avril Lavigne ROCKS.

While it is true that a preferred reading of Lavigne may occur in part as a result of her staged difference from other famous pop performers, it is also true that semiotic structures do not determine meaning; individuals engaging in interaction do. This combination of sociosemiotics and symbolic interactionism allows us to understand how (a) preferred readings usually support existing hegemonic politicoeconomic institutions; (b) signs, such as Avril Lavigne's persona and her preferred fashion props (e.g., skateboard, dickies),${ }^{8}$ express sign value that consumers use to distinguish 
themselves from other consumers; and (c) the difference of a sign from other signs can be used to market commodities and manage impressions of a persona as authentic.

From a semiotic standpoint, every dynamic examined so far works at one specific snapshot-like point in time, known as the synchronic level. But diachrony, or the change of signs and their meanings over time, is central to sociosemiotic analysis. The popular music industry, in particular, the teen pop industry, relies heavily on the previous success of formulas and subgenres. There exist six major global music corporations that share approximately 85 percent of the profits of worldwide music and music-related sales (Shuker 1994). Arista Records is owned by one of these, the German publishing giant Bertellsmann Music Group (commonly known as BMG). Because innovation is risky in such oligopolistic market, CEOs tend to favor productions that follow the tested success of certain sounds and images. Thus, for example, the public personae of pop singers such as Mandy Moore, Jessica Simpson, and Hoku are nothing but corporate responses to the previous success of already popular and similarly commodified personae such as Britney Spears and Christina Aguilera produced by competing production labels (Vannini and Myers 2002). When innovation in this market occurs at all, it often happens through recycling of previous styles, which are presented as "retro" styles, or as a pastiche of the old and the new. The "new," however, is often new only to younger cohorts of consumers who become fans of the latest trend in order to differentiate themselves from previous but very recent trendsetters and trend-followers. Indeed, there may be teenage audiences who embrace Avril Lavigne in order to set themselves apart from Britney Spears fans because they believe her popularity is passé.

In fact, although there is little that is innovative about Avril Lavigne, her similarity to older performers such as Alanis Morisette and Sheryl Crow may escape audiences too young to remember the early 1990s, let alone late 1970s punk. In their eyes Lavigne remains unique even though her music manifests traditional pop sensibility mixed with the smoothed edginess of postpunk (e.g., New Wave, and early and mid-1990s rock singer-songwriter). Nevertheless, Lavigne's persona differs from that of Spears, or Aguilera, or Simpson, or Moore because she represents an innovation in a market saturated with copycats; hence the meaning of her public identity can be coded and marketed as more authentic. In this sense, constructing her image through signs of true punkness like a guitar or a skateboard may in a sense connote punk-rock authenticity. Thus staging the authenticity of such a persona clearly works as a market strategy.

Surely, teenagers are not the only fans. For older audiences less interested in lifestyle and identity matters, her similarity to "older" stars may actually work in her favor. Older audiences may indeed be more prone to purchase a product with which they are familiar. Evidently, diachrony is managed quite profitably.

\section{Oppositional Readings}

While Lavigne's image makers carefully manage her impression of authenticity, more critical consumers may interpret such practices differently. In dramaturgic 
terms, at work here is an information game, that is, a process of information discovery, concealment, modification, and rediscovery that unfolds between the performer and her team and the audience. This information game is complicated by the large amount of discourse available about Lavigne. Hence, critical reviewers can rely not only on their own interpretations but also on other critical interpretations that appear, for example, on underground e-zines and Internet message boards. In addition, oppositional readings of Lavigne's persona, such as the one in the review below from a noncommercial e-zine, tend to focus on the manufactured character of her authenticity and to reflect on the discrepancies in her performances in different settings.

\begin{abstract}
Avril Lavigne is a pop singer feeding off the new punk trend. Apparently she (along with all her fans) missed the bulletin notifying those of us whose minds aren't quite as impressionable that dressing in every article of clothing ever put out by Hot Topic does not make you punk. Yet the brainless youth of America continues to eat it up, as they do with anything and everything they're spoon-fed by the media, top 40 radio, and the sadistic, brainwashing, greedy trend whores better known as MTV executives. In July 14's August issue, Avril explained her songwriting process. "Once I sit down with the guitar, I write about what I'm feeling that day." However, in the July 1st edition of Time magazine, Ms. Lavigne admitted, "I sit down with a guitar player usually." Which is it, Avril? Furthermore, a look at the songwriting credits on her CD will reveal that each song was co-written with a multitude of professional songwriters. One can't help but wonder just how much of these songs was written by Avril. Yet in that same J-14 article, she claimed, "I wrote all those songs when I was sixteen." Avril is being touted as some guitar-playing, songwriting prodigy when, in reality, she's not the only force behind those tracks. But that's what sells, so I guess that makes it alright to lie, exaggerate, and present yourself as some virtuoso. Oh, and here's a bright idea for Avril to prove how punk she is. Let's have her RAP in a song. Because, ya know, most punk bands always include a rap bit or two in their songs. She's a constant contradiction. She skateboards in the video, poses for publicity shots with the board, tells YM magazine that she's good at it. Yet, in an interview with MTV, she discussed how the director of the "Complicated" video wanted her to skate in it. Ms. Tony Hawk ${ }^{9}$ protested, "No, dude, I suck!" One look through any teen magazine will reveal models dressed in clothing just like hers. And let's not forget the fake tattoos she wears on her arms. Because that's like ya know, sooo totally hardcore. Let me go draw a big skull and crossbones on my arm so that I can be punk too. Please. Avril Lavigne just seems fake, plain and simple. ${ }^{10}$
\end{abstract}

So much for gullible youthful audiences! Subcultural membership is a highly salient identity in youths, and many subcultural groups find music meaningful for the definition of their collective identity and group boundaries (Frith 1978; Hebdige 1979). These social boundaries are also known to parallel musical genres (Frith 1978). As Frith (1996) remarks, genres are exclusive and meant to keep people in as much as they are meant to keep others out. Genre boundaries are not permanent-they are shaped by performers as much as by fans-but whenever the rules of a genre are intensely ideological, as in the punk genre, their transgression will cause a strong reaction (Frith 1996). For this reason, many fan reviewers seem to be offended by the corporate manufacturing of Lavigne's punk authenticity and the consequent 
desacralization of the original meaning of punk. When a musical product or persona is branded as a worthy member of an in-group by outsiders, sentiments of protest arise, as the following reviews suggest.

To call her "punk" is to tarnish the images of actual punk artists and their contributions to music as a whole. Please, people, stop listening to this $\mathrm{CD}$, stop wearing socks on your arms, get some real music.

This is really, well, if she was going for pop, then it'd be great, I wouldn't care, just another drone/clone. But she's professing skate-punk, and that is a state of mind, not a fashion.

The thing that most frustrates me about this album specifically and Avril generally is the fact that she is convinced she sings some sort of musical genre called pop/punk. Really, pop singers are dandy. It just irritates me when they try to tell people they're "such a rebel," and yet sing like, oh, I don't know, Avril Lavigne.

Furthermore, audiences question Lavigne's punk authenticity on the basis of the sound of her music. Punk music is traditionally immediate, raw, and free of studio wizardry and other hyperreal production strategies such as the use of Autotune, which automatically tunes the voice with the music. Punk music was originally an angry expression of British working-class youth, and before the late 1970s, when its exposure increased, no money was available for expensive production; the immediacy of the punk sound was virtue made out of necessity. While contemporary punk undoubtedly sounds much "cleaner," overproduction is still interpreted to signify inauthenticity. For instance, the following reviewer reflects on the incoherence between Lavigne's image and her vocal delivery.

I don't know what possessed Avril's people to market Avril as a "skater-punk," but I wish they would stop. There's a huge backlash against her that hardly has anything to do with her music except for the fact that it's not punk. A lot of people remark about Avril's strong vocal delivery, but what those people don't seem to be able to hear is the harsh amount of Autotune that's used on her vocals here. Her voice just clicks into place on most notes and simply doesn't sound natural. This point is driven home by the fact that when she performs live she has major problems staying on pitch. Not to mention that her voice also sounds much heavier live, while on the album it seems to move around effortlessly. That doesn't affect the quality of the album itself, but it just shows those who can't hear the Autotune that Avril's singing is seriously tweaked to sound as perfect as it does here. What I don't like is that her image seems to convey that she's being herself and that she's some sort of anti-Britney, but her vocal talent is just as much a studio creation as Britney's is. She also didn't write any of these songs herself, and the only song she plays guitar in is "Nobody's Fool." Her songwriting and guitar playing skills are just more things that people are fooled into believing in because of Avril's "I'm unique" image. Don't let the hype fool you. It's a fun album, but Avril isn't what she's cracked up to be.

By suggesting that "Avril's people" are wrong to market her as a skater-punk and as real and "unique," this reviewer demonstrates awareness that Lavigne's persona is commodified. Avril is "marketed" as a product by her "people," or team, in dramaturgic terms, to satisfy a presumed market demand. This reviewer clearly understands 
that Lavigne's persona and music are commodities meant to bring in profits and to get "people ... fooled into believing" that this commodity is something else (i.e., an authentic expression). Though the reviewer acknowledges the album is "fun," she also points out that it has been staged to signify something else: punk authenticity. Lavigne's producers manage her persona as a semiotic object that connotes uniqueness, skater-punk subcultural membership, and authenticity. But this reviewer, like many others, is able to read through the ideology hidden in the text: the singing is heavily produced, her guitar playing is minimal, and the lyrics are catchy but superficial. Her presupposed representation of skater-rock or punk authenticity is interpreted by other critically minded audiences against the historical background of what constitutes "true" signification in punk:

If you like mass manufactured entertainment, bully for you. I see no evidence of artistic merit in this collection of highly produced boring scrap. This is perfect music for supermarkets, dentist offices, and airplanes. Sure, she's cute, all dressed in her department store, suburban mall-punk duds. And, by the way, when did pop drivel earn the title of "Punk"? I know I'm getting old, but did I miss something? Punk was something different when I was younger (Stooges, NY Dolls, DK, pre-Rollins Black Flag, even the Ramones and early Clash, etc). In fact, punk was the diametric opposite of everything present in Ms. Lavigne's carefully exploited image.

Avril Lavigne is one of those artists who believe that music and self expression is easily achieved. My belief is that, though such a loose evolving step in music (like much junk out there), the music is so easy to digest and to listen that it makes an unfair attempt in revealing her true persona. Personally, if I were to listen to punk I'd listen to Black Flag (of course, that IS punk) or the Exploited or the Birmingham Crass, but anyway that's something people do not see and therefore do not understand easily. So, buy it if you want, but do not expect a manifesto or a political or mental revolution.

Many reviewers show they are aware of the co-optation of punk that took place in the late 1970s and early 1980s. Since that period, commercial music labels have smoothed the rough musical and lyrical edges of punk to create a more melodic and less politically controversial product in order to appeal to the larger markets of middle-class and mainstream consumers. This New Wave, or postpunk, has much in common with the guitar-driven sensibility of rock but little with the original protest spirit of punk and hardcore (see Gottdiener 1985). Yet, as the following excerpt suggests, the commercial gimmick of constructing Lavigne as a skater-punk rocker may not necessarily work as intended.

I heard her first song on the alternative radio, and it was okay. Then I was watching TV and that "Complicated" video was on TRL. I watched the music video, and was amazed about how much of a poser she was. Then I borrowed the CD from my friend. As I listened to this "skater punk music," I found that it's not punk at all. First, if she thinks her CD is punk, something went wrong with "sk8ter boi," or some odd spelling. Well you probably couldn't make it sound like my 10 year old sister wrote it. So, this CD is made by Britney Spears with a Hot Topic shopping spree. I could probably make Britney sound more punk than her. Don't buy this CD if you like real punk; buy it if you like posers or pop music. 
Those who reject Lavigne's skater-punk subcultural authenticity argue that punk is not meant for signification used to impress others, because "being punk does not come from wearing the right thing." Props such as a skateboard, a guitar, tattoos, and nontraditional clothing and arrangements (such as a necktie worn with cut-off corduroy pants or a pair of dickies and a sock worn over a forearm) are fashion objects used by Lavigne's producers to signify her skater-punk authenticity, but critical audiences may interpret these signifying props negatively. Because the punk look has long been commodified and can be easily purchased at chain stores, anyone can style himself or herself to look punk. And anyone can adopt Lavigne's image. Many fans now show up for Lavigne's concerts wearing dickies, neckties, and arm socks and carrying (but hardly ever riding) a skateboard as well. Producers are well aware of the marketing potential of an artist. The construction of a particular image, when met favorably by audiences, results in increased sales of music-related products and apparel merchandising (Kaplan 1987). But culturally, this commodification of signs has different results. On the one hand, possessing a specific commodity may assign a particular status to its possessor; on the other, even this is a text open for interpretation. A skateboard, for example, does not automatically signify punk authenticity and can instead signify that one is a poseur-in this case, someone who unsuccessfully tries to pass for an authentic subcultural member.

I read in YM that the best skateboard trick she can do is an ollie. Wow! An ollie! My dead grandmother could do an ollie. So she can grind or do a handplant? HAHAHA she's such a good skateboarder.

Following Peterson's (1997) excursus on the meanings of authenticity in country music, one must conclude that the authenticity of a cultural persona and/or product can be staged through the strategic use of a coherent system of signifiers and effective authenticity work. This is not to say that impression management will always work, as oppositional readings testify. Recycling signifiers of authentic artistic expression from a genre's past may work well with some audiences, but other more savvy consumers may be able to see it as mere staging activity. This is so because over time certain signifiers have been commodified and have thus lost their original "authentic" meanings.

Punk, however, resists the demise of meaning. As Gottdiener (1994) has observed, punk as a philosophical and artistic movement is first and foremost about reasserting the primacy of the signified. In this sense punk works as an evident countercultural movement against the postmodern spirit of "floating signifiers," that is, signifiers that have lost their referents. Punk philosophy, in other words, is an attempt to reclaim meaning and denounce the free play of images. True punk therefore is not about looking punk but about being punk. This is a simplistic statement, however, and I must make an important qualification. In fact, we properly ought to speak of punk becoming rather than being. By becoming, that is, by changing diachronically, an authentic subcultural member can remain one step ahead of those who attempt to co-opt meaning. This "escape attempt" (Cohen and Taylor 1978) constitutes 
an act of resistance against attempts to commodify meaning and thus allows subcultures to survive and prosper underground (Muggleton 2000). Now it is on these underground settings where authenticity impression management is performed for subcultural members, and subcultural members only. Within the bounded space of these settings, fellow subcultural members judge authenticity work by constantly evolving criteria and assign street credibility to those who manage impressions successfully. Ultimately, then, authenticity is neither a commodity (though it is often commodified $)^{11}$ nor an essence but rather a constantly changing meaning negotiated by audiences attempting to protect meaningful spaces from the colonizing practices of hegemonic alliances (see Kotarba and Johnson 2002; McCorkel 1998).

\section{AVRIL LAVIGNE'S GENDER PERFORMANCE}

Lavigne's popularity is more than the carefully constructed rise of yet another commercial art product but rather a globally available discursive representation of Western femininity in postmodern society. If seductive pop culture stars like Britney Spears are said to be womanly figures written in the "patriarchal culture as a signifier of the male other, bound by a symbolic order in which man can live out his fantasies and obsessions through linguistic command" (Mulvey 1982:413), Lavigne's gender performance seems quite different at first glance. Her public identity cannot be separated from the performance of her femininity (Butler 1990), and the meanings therein can only be understood in reference to the larger societal ideological system relating to sex and gender (Althusser 1971; Goffman 1979). Her rebellious image and her supposed punk independence must be interpreted against the background of pop culture, which holds an image of the female subject as sexy, alluring, coy, overly (stereotypically) feminine, weak, submissive but seductive, and so on. These representations have been embodied by popular music stars such as Dolly Parton (Frith 1996), Mariah Carey, Kylie Minogue, Mandy Moore, Christina Aguilera, and Britney Spears (on the latter, see Vannini 2002). Critical audiences can then read Lavigne's performance of femininity as a narrative follow-up and as an alternative to prior representations. Because she wears less revealing clothing and less makeup, because she does not "bump and grind" and "moan and pant," and because she does not adhere to the commonly held standards of what constitutes a seductive appearance in contemporary pop culture, her identity is constructed as "alternative," "punk," and even "anti-Britney" (Willman 2002). For example, Willman, an Entertainment Weekly journalist, sees in her the avenger of "real" girlhood:

Thanks to Avril Lavigne, the 18-year-old Canadian whose "Let Go" is the hottest debut album of 2002, butt cheeks, dance beats, and gleeful artifice are suddenly out, while tank tops, rock, and "real" are unexpectedly back in. Pop tarts are assumed to be toast, especially now that tie-wearing tomboy Lavigne has been dubbed "the anti-Britney" by her legions of new supporters. Tom Poleman, who programs one of the country's highest-rated Top 40 stations, ... declares: "Whereas Britney was more glamour and less reality-based, Avril is much more 
the regular kid. For boys, she seems more attainable; girls can see themselves living more like her, dressing the same, being attracted to the same boys." $(2002: 23)^{12}$

Indeed, Lavigne's difference from Spears and Aguilera has allowed her producers to market her as a representation of femininity that is more acceptable to parents worried about the voyeuristic exploitation of female teenager-hood. While some reviewers accept this more conservative front, which arguably serves the interests of her marketing team well, others read this performance counterideologically. But let us begin by looking at preferred readings found in consumer reviews.

The construction of Lavigne's difference works at different levels. First, the difference from her overmanufactured rivals sets her apart as more "real." Second, this representation allows her producers to target not just teens but also older audiencesespecially through the marketing of other singles and B-sides from Let Go such as the mellower "I'm with You" and "Anything But Ordinary." Third, adults will support music that they themselves approve of for their younger children (see Kotarba 2003), as the following reviews suggest.

My teen and preteen daughters love Avril, and this CD gets lots of play in our house. I have to admit I'm rather fond of "Anything But Ordinary" myself. From what my kids have seen of her so far, Avril makes a better role model than most other teen singers.

Finally a girl who won't let "Hollywood" go to her head! First, Britney aimed to our young girls to buy her CDs and as soon as they did and made her millions she's barely wearing clothes and forgetting who made her BIG. Avril wants to be herself. I like her music and it's a CD I do not mind my daughter listening to. She tells people to be themselves, how can that be wrong? So many female singers feel they need to undress to sell but not Avril Lavigne! If you are shopping for a pre-teen or teenager this is one you want to check out!

Fourth, Lavigne's social identity is constructed to differ from similar but older artists such as Alanis Morrissette and Sheryl Crow whose sound and image are familiar to the public and easily recyclable. But whereas Morrissette and Crow perform an "uncomfortable" femininity, as at times they have been openly resentful about and aggressive toward male domination (see Katovich and Makowski 1999), Lavigne is simply "spunky" and independent. She is also just a real, normal, "petite" and "cute" girl "who worries about her hair, fusses about her eyeliner [and] likes to chase cute boys" (Pacienza 2002). In short, she performs a femininity that is acceptable to most consumers.

I can't believe how talented this girl is. This is what young women need to take after: that is, speak your mind, be yourself and don't let people control who you want to be. She has a strong soul and is not afraid to reveal herself. I admire that and wish I could be more like her.

Some critics (Gauntlett 2002) have argued that the rise of empowered and seductive female pop stars who directly or indirectly speak about the plight of women represents a new stage in the history of patriarchy-the rise of popular feminism. Popular feminism is the watered-down version of earlier critical theories of feminism 
that also promote gender equality but support the image-centered view of a voyeuristic and easily marketable "girl power." Examples of this vindication of girl power include cartoon characters like the Powerpuff Girls and music stars like the Spice Girls (Gauntlett 2002) and, more recently, Pink, who is also managed by Lavigne's consultant and Arista Records CEO Antonio "L.A." Reid. In this sense, girl power becomes a valuable commodity, as this noncommercial Web site writer comments:

With her baggy clothes and rebellious attitude, visually she's most young lads dream. She's the girl next door they always wanted. Cool, a bit of a tomboy, but underneath it all she's all girlie girl. Listen to the words of her songs and you'll catch my drift. She's had her heart broken and been caught up in all the regular teenage dramas love throws at you. Where Alanis sang about at times disturbing subjects, Avril sings about regular everyday situations. That's what makes her songs so cool to the younger generations. Avril's hip, she's trendy, she's the hottest thing to hit the female artist market in a long time. ${ }^{13}$

While Lavigne certainly gives the impression of being rebellious and independent, she also reproduces more traditional gender expectations. She seems both hip and hot (in a girl-next-door way), and yet attainable enough to be a desirable female object for men. A few reviewers seem able to deconstruct the ideology hidden behind the signifiers of real girlhood employed by Lavigne and her team. The following consumer review expresses this point clearly.

Her youthful "sexuality" is on display here, if in a much more dignified way than Miss Spears. If you think it's not you're fooling yourself.

The following reviewers instead question not only her punk authenticity but also her independence from masculine domination.

"Complicated" is the worst song that I have heard this year (next to anything by J-LO and Britney Spears). If Avril was truly punk, she wouldn't have this nauseous cutesy pop image that screams out all over MTV.

All of her music sounds the same. It's just like Michelle Branch except Avril doesn't even play the guitar. Whenever she plays on TV she always has "her boys" playing the music. I, being a girl guitarist and songwriter, am very upset by this. Everyone is saying she's so different. Her music sounds the same as any other pop artist.

Because gender is a performance (Butler 1990), even Avril Lavigne's representation of femininity is to be understood as a representamen with the same polysemic properties of other representamens. Gender, history, culture, political economy, and semiotic relations are the frames against which the real and the ideological are constructed at the level of hegemonic production of musical texts and deconstructed at the level of the political aesthetics of interpretation.

\section{CONCLUSION}

The argument running throughout this article is that the signs Avril Lavigne uses to construct her public persona and her performances are open to different interpretations. 
By building on the tradition of dramaturgy and the school of sociosemiotic thought, I have attempted to show how the interpretation of polysemic signs is a practice that is both political and aesthetic. The combined theoretical import of these approaches is important for the development of a symbolic interactionist cultural studies program that sees the communication process, in particular, the act of interpretation, as the meso level where the micro level of personal experience and the macro level of cultural and structural dynamics are mediated (Carey 1989; Denzin 1992; Maines and Couch 1988). The strength of a dramaturgic and sociosemiotic approach to the study of communication lies precisely in its flexibility; it links these different communicative moments at the meso level and pursues a critical and emancipatory agenda that follows the lead of C. Wright Mills, whose enlightening polemic inspired this article.

This interactional, interpretive, and critical view of the politics of aesthetic experience surpasses the limitations of the Frankfurt school of critical theory by transcending its overly simplistic, elitist, pessimistic, semipositivistic, and apocalyptic character (see Kellner 1989). This approach also incorporates Benjamin's (1979) political aesthetics and the British Cultural Studies group's emphasis on hegemony. Moreover, it rejects the traditional distinction between high and low culture, and between the "artistic" and the "popular" by focusing on the meanings of popular culture for its consumers at large. It is in this sense that we can understand interpretation as a primary agentic force and the origin of resistance (Denzin 1992).

As I argued in the introduction, symbolic interactionism has an important role to play in postmodern cultural studies. Informed by Peircean semiotics and its pragmatist foundations, symbolic interactionism can and must emphasize that performance, signs, and meanings have not lost all reference to the real. Certainly, the real is always mediated by our interaction with it, but meanings still have clear value to their users. Commodification practices would destroy meaning if no alternative reading were possible, but a representamen of an object is always interpreted by a social agent, and thus meaning still is real to those who experience its significance. By viewing interpretation as a political and aesthetic practice through which lay audiences reassert the authenticities of meanings, we reopen the doors for a voluntaristic but not naive understanding of the postmodern subject not as a cultural dope but rather as a potentially empowered critic of hegemonic ideologies.

To do so, we must hold a nonessentialist view of the concept of authenticity that does not negate the principle of polysemy. From a dramaturgic and sociosemiotic perspective, this postmodern authenticity potentially results from the process of shaping and giving meaning to polysemic texts and performances. Therefore, the authenticity of a cultural product resides neither in its essence nor in its "authenticity" prior to signification but in its becoming meaningful through an interactive process. Indeed, both in Peircean semiotics and in Meadian thought no meaningful entity is given to us without the mediation of the interpretive act. Authenticity is therefore a noun as much as it is a verb, or in other words, a property and simultaneously a process. As described throughout this article in relation to the interpretation of Avril 
Lavigne, the diachronic process, or semiosis, always takes place in an exosemiotic context defined by historical, aesthetic politicoeconomic, cultural, and ideological relations. Because in an advanced capitalist society this context is marked by hegemonizing practices of commodification of cultures and lifestyles, the authenticity process works as a reappropriation of meaningful space.

The reappropriation of meaningful and authentic space is an act of resistance that resembles closely the construction of critical space described by McCorkel (1998). A critical space is a temporary autonomous zone where individuals resist institutional forces such as the hegemonizing and commodifying practices described here. Through their oppositional readings, critics of Avril Lavigne vindicate spaces on the Internet where they subvert her identity claims and contest the logic of pop culture. Dwellers in a critical space question the legitimacy of institutional authority while formulating "alternate conceptual frameworks which challenge [pop culture] discourse and allow them to interpret their life experiences in a way that sustains alternate definitions of self" (McCorkel 1998:247). Like hegemonies, critical spaces are only temporary. If hegemony, as defined by Gramsci (1971), is the site of cultural struggle, a critical space is a subsection of that site where resistance has momentarily prevailed. Thus social alliances attempting to form and maintain politicocultural hegemonies are always engaged in a dialectic struggle with more or less organized groups of individuals claiming the autonomy to define meanings and change them in order to resist co-optation. This is a continuously developing process that forces all students of popular culture, in particular, social semioticians, to examine the process of semiosis in diachronic terms. Finally, critical spaces expand and contract in response to the waxing and waning force of cultural hegemonies. It is through the interpretive act that in-group members vary the intensity of their defense of the ideological authenticity of a genre of music and thus resist co-optation.

Acknowledgments: Simon Gottschalk and the three anonymous reviewers for Symbolic Interaction helped me immensely with the development of the final version of this article. I would also like to acknowledge the assistance of Viktor Gecas, Aaron McCright, and April Warn.

\section{NOTES}

1. I define ideology, following Althusser (1971:165), as the "imaginary relations of individuals to the real relations in which they live and which govern their existence," but I deviate from Althusser's antihumanistic skepticism.

2. Polysemy must, however, be understood in relative terms. Individuals are socialized into their particular culture and therefore do share common symbolic meanings, understandings, practices, and so on (Mead 1934).

3. It is important to emphasize that hegemony is not equivalent to static domination; rather, it is continuous struggle, with culture as the discursive and material site of the struggle (Gramsci 1971).

4. Excerpts from reviews reproduced here are used courtesy of Amazon.com and Yahoo.com unless otherwise noted. All rights reserved. 
5. I am referring here especially to the existential underpinnings of Goffman's work and in particular to his concern for actors performing in bad faith. The study of authenticity in everyday life is directly connected to issues of power, ideology, and representation, but despite early attention to the possibility of connecting dramaturgy to issues of semiotics and power (see Ditton 1980) Goffman's theory has never been integrated into social semiotics.

6. Evidently, the concept of authenticity itself is ideological from the start, which begs the question: how can we espouse polysemy while embracing the quasi-essentialist notion of authenticity? The solution lies in understanding authenticity as rooted in pragmatism and not in essentialism (Holstein and Gubrium 2000). In this sense, "real" and "authentic" punk subcultural membership means rejection of the commodified mainstream, counterhegemonic cultural struggle, a concern with depth rather than surface, the promotion of self-expressiveness, originality, and creativity, and the appreciation of independently produced, raw and "immediate" (i.e., not overproduced) rock music. This approach parallels common understandings of punk shared by members and critics (e.g., Frith 1978; Grossberg 1992; Hebdige 1979). The skateboard subculture shares much in common with the punk subculture (see Borden 2000). Because it is well known that punk has been co-opted, transformed, and commodified in order to be more widely sold as a commercial product (Gottdiener 1985), guilty as charged I consider this later commodified version "inauthentic."

7. Misspellings and grammatical errors in the original reviews were corrected. To render the reviews more readable, I also adjusted punctuation and omitted ellipsis. Because of space limitations, some passages that appeared in the original reviews have been omitted.

8. Dickies are pants often worn by skateboarders.

9. Tony Hawk is the most notorious professional skateboarder.

10. Review by Jessica Zietz at http://recroommagazine.com/framesmain.htm. Web site last accessed on April 13, 2003. Permission obtained.

11. Let it be clear that my treatment of Avril Lavigne as inauthentic is not grounded in the ideological belief that all of popular culture is inauthentic, as Adorno would have it. Art is a form of personal expression, and it does not matter what medium it takes (high, low, folk, etc.). But whenever this form of expression is mediated by marketing strategies and is commodified, its deeply personal expressiveness is compromised and thus it becomes inauthentic.

12. This is an article written by a compensated professional journalist, and therefore was not included in my sample of consumer reviews.

13. Review found at http://www.themayfairmall.com/Mayfair_zine_cdrev_avril.htm. Web site last accessed on April 13, 2003. Permission obtained.

\section{REFERENCES}

Adorno, Theodor. 1976. Introduction to the Sociology of Music. Translated by E. B. Ashton. New York: Seabury Press.

.1991. The Culture Industry: Selected Essays on Mass Culture. Edited by J. Bernstein. London: Routledge.

Althusser, Louis. 1971. Lenin and Philosophy and Other Essays. New York: Monthly Review.

Ang, Ien. 1985. Watching Dallas: Soap Opera and the Melodramatic Imagination. London: Methuen.

Barthes, Roland. 1972. Mythologies. New York: Hill and Wang.

-1985. The Grain of the Voice: Interviews, 1962-1980. New York: Hill and Wang.

Becker, Howard. 1982. Art Worlds. Berkeley: University of California Press.

Benjamin, Walter. 1979. Selected Works. London: New Left Books.

Borden, Iain. 2000. "Speaking the City: Skateboarding Subculture and Recompositions of the Urban Realm." Research in Urban Sociology 5:135-54.

Butler, Judith. 1990. Gender Trouble: Feminism and the Subversion of Identity. New York: Routledge. Carey, James. 1989. Communication as Culture. Boston: Unwin Hyman.

Certeau, Michel de. 1990. The Practice of Everyday Life. Translated by S. Rendall. Berkeley: University of California Press. 
Cohen, Stanley and Laurie Taylor. 1978. Escape Attempts: The Theory and Practice of Resistance to Everyday Life. New York: Penguin Books.

Crook, Stephen, Jan Pakulski, and Malcolm Waters. 1992. Postmodernization: Change in Advanced Society. London: Sage.

DeNora, Tia. 2000. Music in Everyday Life. Cambridge: Cambridge University Press.

Denzin, Norman K. 1987. "On Semiotics and Symbolic Interactionism." Symbolic Interaction 10:1-19.

1992. Symbolic Interactionism and Cultural Studies: The Politics of Interpretation. Cambridge: Blackwell.

. 2003. "The Call to Performance." Symbolic Interaction 26:187-208.

Dewey, John. 1934. Art as Experience. New York: Putnam.

Ditton, Jason, ed. 1980. The View from Goffman. New York: St. Martin's Press.

Fairclough, Norman. 1995. Critical Discourse Analysis: The Critical Study of Language. London: Longman.

Featherstone, Mike. 1991. Consumer Culture and Postmodernism. London: Sage.

Fine, Gary Alan. 1977. "Popular Culture and Social Interaction: Production, Consumption, and Usage." Journal of Popular Culture 11:453-66.

Fiske, John and John Hartley. 1978. Reading Television. London: Methuen.

Frith, Simon. 1978. The Sociology of Rock. London: Constable. 1983. Sound Effects: Youth, Leisure, and the Politics of Rock 'n Roll. London: Constable. 1996. Performing Rites: On the Value of Popular Music. Oxford: Oxford University Press.

Gauntlett, Simon. 2002. Media, Gender, and Identity. London: Blackwell.

Goffman, Erving. 1959. The Presentation of Self in Everyday Life. New York: Anchor Books. - 1967. Interaction Ritual: Essays in Face to Face Behavior. Chicago: Aldine. 1969. Strategic Interaction. Philadelphia: University of Pennsylvania Press. 1974. Frame Analysis. New York: Harper and Row. 1979. Gender Advertisements. Cambridge, MA: Harvard University Press.

Gottdiener, Mark. 1985. "Hegemony and Mass Culture: A Semiotic Approach." American Journal of Sociology 90:979-99. . 1994. "Semiotics and Postmodernism." Pp. 155-81 in Postmodernism and Social Inquiry, edited by D. Dickens and A. Fontana. New York: Guilford Press.

Gramsci, Antonio. 1971. Selections from the Prison Notebooks. New York: International Publishers.

Grossberg, Lawrence. 1992. We Gotta Get Out of This Place: Popular Conservatism and Postmodern Culture. New York: Routledge.

Hall, Peter M. 1988. "Asimmetry, Information Control, and Information Technology.” Pp. 341-56 in Communication and Social Structure, edited by D. Maines and C. Couch. Springfield, IL: Charles Thomas.

Hall, Stuart. 1980. "Encoding/Decoding." Pp. 128-38 in Culture, Media, and Language: Working Papers in Cultural Studies, 1972-1979, edited by S. Hall. London: CCCS University of Birmingham Press.

Hebdige, Dick. 1979. Subculture, the Meaning of Style. London: Methuen. . 1988. Hiding in the Light. London: Routledge.

Hodge, Robert and Gunther Kress. 1988. Social Semiotics. Ithaca, NY: Cornell University Press.

Holstein, James and Jaber Gubrium. 2000. The Self We Live By: Narrative Identity in a Postmodern World. New York: Oxford University Press.

Kaplan, E. Ann. 1987. Rocking Around the Clock: Music Television, Postmodernism, and Consumer Culture. New York: Methuen.

Katovich, Michael A. and Marya Makowski. 1999. "Music Periods in the Rock and Post Rock Eras: The Rise of Female Performers on a Provocative Stage." Studies in Symbolic Interaction 22:141-66.

Kellner, Douglas. 1989. Critical Theory, Marxism, and Modernity. Baltimore: Johns Hopkins University Press.

Kotarba, Joseph. 2002. “Rock 'n' Roll Music as a Timepiece.” Symbolic Interaction 25:397-404. 
2003. "Our Parents' Music.” Paper presented at the Couch-Stone Symposium of the Society for the Study of Symbolic Interaction, Tempe, AZ.

Kotarba, Joseph and John Johnson. 2002. Postmodern Existential Sociology. Walnut Creek, CA: Alta Mira.

Kroker, Arthur. 1992. The Possessed Individual: Technology and the French Postmodern. New York: St. Martin's Press.

Lee, Edmund. 2002. "What She Wants Is What She Gets." New York Times, November 24, p. 31.

Lefebvre, Henri. 1971. Everyday Life in the Modern World. New Brunswick, NJ: Transaction Books.

Maines, David and Carl Couch, eds. 1988. Communication and Social Structure. Springfield, IL: Charles Thomas.

McCorkel, Jill. 1998. "Going to the Crackhouse: Critical Space as a Form of Resistance in Total Institutions and Everyday Life." Symbolic Interaction 21:227-52.

Mead, George Herbert. 1934. Mind, Self and Society. Chicago: University of Chicago Press.

Meyrowitz, Joshua. 1985. No Sense of Place: The Impact of Electronic Media on Social Behavior. New York: Oxford University Press.

Mills, C. Wright. 1963. Power, Politics, and People: The Collected Essays of C. Wright Mills. Edited with an introduction by I. Horowitz. New York: Ballantine.

Muggleton, David. 2000. Inside Subculture: The Postmodern Meaning of Style. Oxford: Berg.

Mulvey, Laura. 1982. "Visual Pleasure and Narrative Cinema." Screen (autumn):412-28.

Pacienza, Angela. 2002. "Teen Pop Rocker Avril Lavigne Rising to Top of Charts with AntiPoseur Songs." Canadian Press, June 3. Available at http://avrilonline.org/html/core.php? $\mathrm{z}=$ canadianpress. html. Last accessed June 9, 2003.

Peirce, Charles S. 1960. Collected Papers of Charles Sanders Peirce. Vols. 1-6. Cambridge, MA: Harvard University Press.

Peterson, Richard. 1997. Creating Country Music: Fabricating Authenticity. Chicago: University of Chicago Press.

Radway, Janice. 1984. Reading the Romance: Women, Patriarchy, and Popular Literature. Chapel Hill: University of North Carolina Press.

Shuker, Roy. 1994. Understanding Popular Music. London: Routledge.

Vannini, Phillip. 2002. "Adorno's Legacy: On Critical Theory, Cultural Studies, and the Global Political Economy of Britney Spears Inc. Illuminations. Available at http://www.gseis.ucla.edu/ faculty/kellner/Illumina\%20Folder/adornolegacy.htm. Last accessed April 16, 2003.

Vannini, Phillip and Scott Myers. 2002. "Crazy about You: Reflections on the Meanings of Contemporary Teen Pop.” Electronic Journal of Sociology 6. Available at http://www.sociology. org/content/vol006.002/vannini_myers.html. Last accessed April 16, 2003.

Willman, Chris. 2002. "The Anti-Britney?" Entertainment Weekly, November 1, p. 23. 